\title{
University Students' Self-efficacy in Online Learning Due to COVID-19
}

\author{
${ }^{1}$ Erni Tanius, ${ }^{2}$ Nur Iman Aqila Alwani, ${ }^{3}$ Salman Abdul Muein \\ ${ }^{1}$ Lecturer, ${ }^{2}$ Student, ${ }^{3}$ Student \\ Faculty of Business and Accountancy, \\ Universiti Selangor, Shah Alam, Selangor, Malaysia
}

\begin{abstract}
COVID 19 shocked the world; it changes everybody's life, especially in education and online learning becomes a new culture. Hence, this study will identify the correlation between learners' motivation, computer anxiety, and social support with self-efficacy on online learning technology due to COVID 19 pandemic. Besides, to determine if there are any gender and age differences in their perception of online learning technology. 166 students in a university were using online learning for the first time participated in this study. The correlation analysis and chi-square are used to answer the objective of the study. The result indicated that online learning technology experience, learners' attitudes, learners' motivation, computer anxiety, and social support correlate with self-efficacy on online learning technology. Furthermore, the finding revealed that male and female respondents and different ages have similar opinions on the factors that contribute to online learning technology.
\end{abstract}

Index Terms: Self-efficacy, university' students, online learning technology experience, learners' attitudes, learners' motivation, computer anxiety, and social support

\section{INTRODUCTION}

The COVID 19 pandemic affected almost all the countries, including Malaysia. Hence, Malaysian Prime Minister Muhyiddin Yassin officially announced the Control Movement Order (CMO) based on the Prevention and Control of Infectious Diseases Act 1988 and the Police Act 1967 On 16 March 2020, [1]. As a result, it changes every segment of life, especially in the education system. The educational institutions closed, and home-based learning by using online learning technology is mandatory.

Due to sudden implementation, the stakeholders in education claimed they are not ready. There are some issues related to online learning technology issues such as technology-related anxiety due to out of one's comfort zone, inequity in evaluation, and perceived incapacity or difficulty in peer interaction and the presentations [2]. Another problem highlighted by Bandura, which is self-efficacy on online learning technology, is learners' ability to manage their learning.

Literature indicated that motivation, readiness, and self-regulated learning contribute to students' self-efficacy toward online learning technology. [4]. besides, it requires skills in computer, internet, and information-seeking skills [5].

Hence, the objective is to identify a correlation between factors contributing to self-efficacy in online learning and students' performance. Besides, to determine if gender and age wBesidesfluence it. However, this study only focuses on online learning technology experience, learners' attitude, learners' motivation, computer anxiety, and social support as the factors contribute to selfefficacy on the university students' online technology.

\section{LITERATURE REVIEW}

\section{Self-efficacy}

Bandura [6] defined self-efficacy as the belief of an individual in their ability to fulfill a task in a different circumstance. He added that it is affecting the individual's choice of behaviors, commitment, and persistence. Besides, it will influence goal choices [7], and the degree of perseverance met with difficulties [7, 8]. Self-efficacy is influenced by four factors: mastery experience, vicarious experience, verbal or social persuasion, and physiological and affective states [8].

Meanwhile, Alqurashi [5] refers to self-efficacy as the belief in one's ability to organize and carry out the courses of action necessary to achieve these achievements. It predicts the motivation, execution, and the degree to which individuals' desire a specific outcome compared to other alternatives [8]. Individuals with high self-efficacy often show a good feeling of well-being and overall high selfesteem [10]. The self-efficacy sources include experience in accomplishing a task, vicarious experience, and verbal persuasion [11]. It also affects the physiological and perceives the ability of individuals' awareness [9].

Self-efficacy influences personal objectives directly and indirectly and relates with academic setting motivates and achievement [8]. As well as encourages the elimination of unwanted emotional reactions. Finally, students with higher academic self-efficacy experience less stress in school than those who doubt their self-efficacy and abilities [12]. 


\section{Online Learning Technology Experience}

Online learning' is referred to as courses offered entirely online; that fully or only partially use any electronic device or network [17, 18]. In teaching and learning, the physical classroom is replaced with web-based technologies [19]. It knows as distance learning, elearning, online learning, blended learning, web-based learning, virtual learning, tele-education, cyberlearning, internet-based learning, and distributed learning [16].

Meanwhile, online learning technology experience defines by Keller and Chitnis[13] and Tharhini [14] as the use of information and communication technology (ICT). It provides education knowledge where teachers and learners are divided by distance, time, or both to improve learning experience and success. Online technological trends become trends, especially on online purchases, reading, and finding directions [15].

Online learning technology can improve the understanding of learning. Besides, it increases the more robust sense of community among students and reduces withdrawal or failure [20]. On the other hand, [20] said that online learning technology is difficult to understand, especially when the computer is slow or low internet. It creates more problems rather than its solution. Hence, the learner technology experience is crucial to ensure the online learning technology is booming.

\section{Learners Attitude}

Guyer, Joshua, and Fabrigar, Leandre [22] define learners' attitude as a relatively general and permanent assessment of an object, person, or concept in a positive to negative dimension. Meanwhile, Dursun, Donmez, and Akbulut [23] said it is an individual attitude towards the learning situation. It represents both positive or negative conduct and reflection of feelings and information of a specific idea or subject matter [24].

Attitude plays a vital role in online learning [25] as it is crucial and necessary to accept and adopt online learning [21]. Meanwhile, Rhema \& Miliszewska [26] added that age, gender, confidence level contribute to the learners' motivation. Besides, technical skills such as frequency of computer use, ICT work experience, own technical possession, ICT access, and ICT training history [27]. Finally, Peytcheva-Forsyth, Yovkova, and Aleksieva [27] conclude that online learning's critical factor depends on the learner's attitude and perception towards online learning itself [27].

\section{Learners' Motivation}

Brown [28] describes motivation as an inner force, impulsive, emotional, or desire which moves one to the action. It is crucial to learn and influence what, when, and how we learn and is a significant performance factor [29]. Motivation use of tactics to help achieve objectives [30] and affect what learner learns how they learn, and when they decide to learn [29].

In learning by using technology, motivation plays as self-regulated learning for learners [31]. The main characteristics of motivations are specific, motivation, goals of success, confidence, self-efficacy, and confidence in power [32]. It is an intrinsic motivation in online learning [29] and influences the learners' ability to perform their tasks [6]. Lastly, Ullah and Obaid [21] conclude that the learners' motivation in online learning can enhance the productivity of students.

\section{Computer Anxiety}

Computer anxiety refers to a fear of computers' emotional responses, including disturbance, fear, apprehension, and agitation. it causes unnecessary fear of physiological effects [35]. Salamah, Ganiardi, and Kusumanto [36] claimed that computer anxiety is a negative stress was associated with one specific form of stress computer beliefs, problem, a problem with the use of computers, and machine rejection. In the times, V. Celik and E. Yesilyurt [37] found out that computer anxiety, attitude to technology, perceived computer self-efficacy are important predictors of teacher candidates' attitude toward using computer supported education. Saadé, Kira, Mak, and Nebebe [38], found out that essential students have experienced anxiety with online learning classes. They also indicated that female students are more anxious about taking online courses than males. However, Thinakaran, Ali, and Husin [39] said that the level of anxiety about using computers amongst undergraduate students is low.

\section{Social Support}

Sahin-Baltaci and Karatas [40] describe social support as the knowledge that allows the person to believe they are cherished, respected, cared for, and a member of the social network. It is as an appreciation through the exchange of physical or psychosocial means [41]. The social support received reflects significant others' existing resources, such as family members, friends, and partners [42]. The social support for online learning in tertiary institutions is crucial, especially for support from the community, family, and community, said Andi Wahyu Irawan, Dwisona [43]. A study by Lai et al. [44] found similar results: the parents play a significant role in supporting their children. Finally, Sawahel [45] recommended that higher education policy-makers collaborate with the telecommunication industry to provide internet facilities for faculty members and students to facilitate online learning.

\section{Methodology}

The collected data in this study is using primary data by constructing a questionnaire. 166 respondents from the university in Shah Alam joined in this study. The variables developed from previous related studies and designed purposely to answer the study's objective. Finally, the data analyzed by using descriptive statistics, correlation, and the Chi-Square test. 


\section{Reliability Test}

The pilot test was conducted to identify the questionnaires' reliability; the pilot test is conducted to 30 respondents. The Mallery (2003) used to determine the internal consistency of items in the scale.

Table 1: Reliability Test

\begin{tabular}{|l|l|}
\hline Dimension & Cronbach's Alpha \\
\hline Online Learning Technology Experience & .807 \\
\hline Learners' Attitude & .831 \\
\hline Learners' Motivation & .954 \\
\hline Computer Anxiety & .872 \\
\hline Social Support & .945 \\
\hline Self-Efficacy & .948 \\
\hline
\end{tabular}

As shown in table 1, the result indicated Cronbach's Alpha values for each variable above 0.8 . Hence, the variable considers reliable and appropriate use as the variable for this study.

\section{FINDING}

\section{The background of Respondents}

Table 2 Summary of Respondent

\begin{tabular}{|c|c|c|c|}
\hline \multicolumn{2}{|c|}{ Demographic Variables } & \multirow{2}{*}{\begin{tabular}{|c|} 
Frequency $(\mathbf{N})$ \\
58
\end{tabular}} & \multirow{2}{*}{$\frac{\text { Percent (\%) }}{34.9}$} \\
\hline Gender & Male & & \\
\hline & Female & 108 & 65.1 \\
\hline \multirow[t]{3}{*}{ Age } & 21 or less & 44 & 26.5 \\
\hline & $21-25$ & 107 & 64.5 \\
\hline & 26 or more & 15 & 9.0 \\
\hline \multirow[t]{5}{*}{ Religion } & Muslim & 146 & 88.0 \\
\hline & Buddha & 2 & 1.2 \\
\hline & Hindu & 5 & 3.0 \\
\hline & Christian & 12 & 7.2 \\
\hline & Others & 1 & .6 \\
\hline \multirow[t]{4}{*}{ Ethnic } & Malay & 137 & 82.5 \\
\hline & Chinese & 1 & .6 \\
\hline & Indian & 7 & 4.2 \\
\hline & Others & 21 & 12.7 \\
\hline \multirow[t]{6}{*}{ Program } & HRM & 66 & 39.8 \\
\hline & Business & 33 & 19.9 \\
\hline & TESL & 30 & 18.1 \\
\hline & Medical & 7 & 4.2 \\
\hline & Engineering & 19 & 11.4 \\
\hline & Others & 11 & 6.6 \\
\hline \multirow[t]{2}{*}{ Education } & Diploma & 69 & 41.6 \\
\hline & Degree & 97 & 58.4 \\
\hline \multirow[t]{5}{*}{ Platform } & BigBlueButton & 60 & 36.1 \\
\hline & Zoom & 27 & 16.3 \\
\hline & Google Meet & 42 & 25.3 \\
\hline & Google Classroom & 19 & 11.4 \\
\hline & Others & 18 & 10.8 \\
\hline
\end{tabular}

Based on table 2, more than half of the respondents (65\%) are female and 58 (34.9\%) are male. Majority or 107 (64.5\%) in the age of 21 to 25 years old, followed by 21 years old or less (44 or 26.5\%). Mainly they are Muslim (146 or $88 \%$ ) and the second is Christian (12 or 7.2\%). In term of ethnicity, mostly Malay (82.5\%) and others (12.7\%) it includes international students and students from Sabah and Sarawak). 39.8\% of respondent's study Human Resource Management students, 19.9\% Teaching English as Second Language (TSEL) students meanwhile engineering students contribute to $11.4 \%$ of respondent in this study. The proportion of level study, the bachelor students slightly higher (58.4\%) compare to Diploma students $(41.6 \%)$. The respondents claimed that they used Big Blue Button as the primary online learning platform (36.1\%), another 25.3\% said they are using Google Meet, and $16.3 \%$ used Zoom.

\section{Correlation Analysis}

The analysis would like to identify the correlation between factors that contribute to self-efficacy (online learning technology experience, learners' attitude, learners' motivation, computer anxiety, and social support) and self-efficacy for using online learning technology in universities at Shah Alam. The correlation analysis will be based on the following hypotheses: 
Ho: There is no significant correlation between factors that contribute to self-efficacy (online learning technology experience, learners' attitude, learners' motivation, computer anxiety, and social support) and self-efficacy for using online learning technology in universities at Shah Alam.

H1: There is a significant correlation between factors that contribute to self-efficacy (online learning technology experience, learners' attitude, learners' motivation, computer anxiety, and social support) and self-efficacy for using online learning technology in universities at Shah Alam.

In the meantime, Pearson's correlation coefficient is used to measure the strength of a linear relationship between paired data. It is based on Evans (1996) suggests for the absolute value of $r$ :

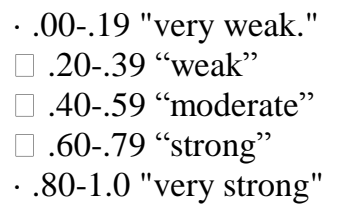

Table 3: Correlation Table between Factors of Self-Efficacy and self-efficacy on Online Learning Technology

\begin{tabular}{|c|c|c|c|}
\hline & & totaldv1 & Totaliv1 \\
\hline \multirow{3}{*}{ Experience } & Pearson Correlation & 1 & $.495^{* *}$ \\
\hline & Sig. (2-tailed) & & .000 \\
\hline & $\mathrm{N}$ & 166 & 166 \\
\hline \multirow{3}{*}{ Learner's attitude } & Pearson Correlation & 1 & $.313 * *$ \\
\hline & Sig. (2-tailed) & & .000 \\
\hline & $\mathrm{N}$ & 166 & 166 \\
\hline \multirow{3}{*}{ Learner's motivation } & Pearson Correlation & 1 & $.578^{* *}$ \\
\hline & Sig. (2-tailed) & & .000 \\
\hline & $\mathrm{N}$ & 166 & 165 \\
\hline \multirow{3}{*}{ Computer Anxiety } & Pearson Correlation & 1 & $.158^{*}$ \\
\hline & Sig. (2-tailed) & & .042 \\
\hline & $\mathrm{N}$ & 166 & 166 \\
\hline \multirow{3}{*}{ Social Support } & Pearson Correlation & 1 & $.695^{* *}$ \\
\hline & Sig. (2-tailed) & & .000 \\
\hline & $\mathrm{N}$ & 166 & 166 \\
\hline
\end{tabular}

Overall, as shown in table 3, there is a positive correlation between all the factors contributing to self-efficacy. They are online learning technology experience, learners' attitude, learners' motivation, computer anxiety, and social support) Furthermore, selfefficacy for using online learning technology, all the p-value $<0.05$. Hence the $\mathrm{H} 1$ accepted, and Ho rejected. It can conclude that online learning technology experience, learners' attitudes, learners' motivation, computer anxiety, and social support significantly influence the respondents' self-efficacy for using online learning technology.

However, the strength differs from weak to strong. Based on above table there was a strong, positive correlation between social support and self-efficacy $(\mathrm{r}=.695, \mathrm{~N}=166, \mathrm{p}<.001)$. However, the correlation between learners' motivation and self-efficacy is moderate $(\mathrm{r}=.578, \mathrm{~N}=166, \mathrm{p}<.001)$. It is similar to correlation between online learning experience and self-efficacy $(\mathrm{r}=.495$, $\mathrm{N}=166, \mathrm{p}<.001)$. Result indicated that learners' attitude has weak correlation with self-efficacy $(\mathrm{r}=.313, \mathrm{~N}=166, \mathrm{p}<.001)$. Finally, the result revealed that computer anxiety has very weak correlation with self-efficacy $(r=.158, N=166, p<.001)$.

The respondents in this study agreed that the main factors that correlate with their self-efficacy on online learning technology are social support. It means that support from their parents, lecturers, and friends plays a vital role in influencing their self-efficacy using online learning technology. It is exciting to show that their motivation and attitude only moderately influence their self-efficacy on online learning technology. Finally, even though computer anxiety has significant with self-efficacy, however, it is very weak. It is a good sign that mainly respondents have experience in online technology; this is the first time online learning has become mandatory. Chi-Square Test

In this study, researchers are running the Chi-Square test to identify the relationship between the respondent's genders, the respondent's age, and the dependent variable (self-efficacy) to identify the relationship.

The analysis of the chi-square based on the following hypothesis:

Ho: There is no significant relationship between genders and self-efficacy in online learning technology universities at Shah Alam. H1: There is a significant relationship between genders and self-efficacy in online learning technology universities at Shah Alam. 
Table 4 Chi-Square Table between Genders and Self-Efficacy

\begin{tabular}{|l|l|l|l|}
\cline { 2 - 4 } \multicolumn{1}{c|}{} & & & $\begin{array}{l}\text { Asymptotic Significance } \\
(2-\text {-sided })\end{array}$ \\
\hline Pearson Chi-Square & Value & df & .120 \\
\hline Likelihood Ratio & $31.133^{\mathrm{a}}$ & 23 & .027 \\
\hline Linear-by-Linear Association & 37.820 & 23 & .116 \\
\hline N of Valid Cases & 2.474 & 1 & \\
\hline
\end{tabular}

a. 36 cells $(75.0 \%)$ have an expected count of less than 5 . The minimum expected count is .35 .

As shown in table 4, shows that there is no significant relationship between genders and self-efficacy. Since the p-value is greater than .005 (Pearson Chi-Square $=.120>.005$ ), H0 is accepted and H1 is rejected. It shows that there is not enough evidence to suggest a significant relationship between genders and self-efficacy. Therefore, genders were found no relationship between self-efficacy.

Table 5 Chi-Square Table between Age and Self-Efficacy

\begin{tabular}{|l|l|l|l|}
\cline { 2 - 4 } \multicolumn{1}{c|}{} & Value & df & $\begin{array}{l}\text { Asymptotic Significance (2- } \\
\text { sided) }\end{array}$ \\
\hline Pearson Chi-Square & $55.477^{\mathrm{a}}$ & 46 & .160 \\
\hline Likelihood Ratio & 65.264 & 46 & .032 \\
\hline Linear-by-Linear Association & 4.564 & 1 & .033 \\
\hline N of Valid Cases & 166 & & \\
\hline
\end{tabular}

a. 62 cells $(86.1 \%)$ have an expected count of less than 5 . The minimum expected count is .09.

The analysis of the chi-square result is based on the hypothesis below:

Ho: There is no significant difference between age and self-efficacy on online learning technology in Shah Alam universities.

H1: There is a significant difference between age and self-efficacy on online learning technology in Shah Alam universities.

As shown in table 4, there is no significant relationship between age and self-efficacy. Since the p-value is greater than .005 (Pearson Chi-Square $=.160>.005), \mathrm{H} 0$ is accepted and H1 is rejected. It shows that there is not enough evidence to suggest a significant relationship between age and self-efficacy. Therefore, age was found no relationship between self-efficacy.

\section{Conclusion and Recommendation}

This study's most significant finding reveals that students have self-efficacy on online learning technology, even though this is the first time they use it as mandatory learning. The study also highlighted that social support in online learning. Interestingly, the study's findings also indicated that females and males and different ages have similar opinions on the factors that contribute to online learning technologies.

Overall, the study is beneficial to higher learning institutions, academicians, students, and society. Besides, it contributes to the world of knowledge in the area of technology for teaching and learning. Each of the stakeholders can know their role and contribution to the ease of online learning.

However, this study has some limitations, such as the key factors limiting to online learning technology experience, learners' attitudes, learners' motivation, computer anxiety, and social support. Besides, the sample's number only limit to universities in a city, which may not generalize the large population. Hence, future study is needed with other different factors and with the large population. Finally, the comparison study among universities and different states or different countries, or different methodology such as qualitative, can understand more on factors that contribute to self-efficacy on online learning among university students.

\section{REFERENCES}

[1] Tang, A. (2020). "Malaysia announces movement control order after spike in Covid-19 cases (updated)". The Star. Retrieved on 18 March 2020.

[2] Gillett-Swan, J. (2017). The Challenges of Online Learning: upporting and Engaging the Isolated Learner. Journal of Learning Design, 10(1), 20.

[3] Hodges, C. B. (2018). Self-efficacy in the context of online learning environments: A review of the literature and directions for research. Performance Improvement Quarterly, 20(3-4), 7-25.

[4] Keskin, S., \& Yurdugül, H. (2020). Factors Affecting Students' Preferences for Online and Blended Learning: Motivational Vs. Cognitive. European Journal of Open, Distance and E-Learning, 22(2), 72-86.

[5] Alqurashi, E. (2016). Self-Efficacy in Online Learning Environments: A Literature Review. Contemporary Issues in Education Research (CIER), 9(1), 45-52. https://doi.org/10.19030/cier.v9i1.9549

[6] Bandura, A. (1997). Self-efficacy: The exercise of control. W H Freeman/Times Books/ Henry Holt \& Co.

[7] Bandura, A., \& National Inst of Mental Health. (1986). Prentice-Hall series in social learning theory. Social foundations of thought and action: A social cognitive theory. Prentice-Hall, Inc.

[8] Lee, P. C., \& Mao, Z. (2016). The relation among self-efficacy, learning approaches, and academic performance: an exploratory study. Journal of Teaching in Travel \& Tourism, 16(3), 178-194. 
[9] Hendricks, K. S. (2016). The Sources of Self-Efficacy: Educational Research and Implications for Music. Update: Applications of Research in Music Education, 35(1), 32-38.

[10] Flammer, August. (2015). Self-Efficacy. 10.1016/B978-0-08-097086-8.25033-2.

[11] Krishnan, A., Barnett, K., McCormick, J., \& Newcombe, G. (2016). A social cognitive investigation of Australian independent school Boards as teams. Journal of Educational Administration, 54(3), 288-304.

[12] Verešová, Marcela \& Foglová, Lucia. (2018). Academic Self-Efficacy, Approach to Learning and Academic Achievement. 10.5772/intechopen.70948.

[13] Keller, M.J., and Chitnis, A.B. (2007) Insights into the evolutionary history of the vertebrate zic3 locus from a teleostspecific zic6 gene in the zebrafish, Danio rerio. Development genes and evolution. 217(7):541-547.

[14] Tarhini, A., El-Masri, M., Ali, M., \& Serrano, A. (2016). Extending the UTAUT model to understand the customers' acceptance and use of internet banking in Lebanon. Information Technology \& People.

[15] Schindler, L.A., Burkholder, G.J., Morad, O.A. et al. Computer-based technology and student engagement: a critical review of the literature. International Journal of Education Technical High Education 14, 25 (2017).

[16] Sun, A., \& Chen, X. (2016). Online education and its effective practice: A research review. Journal of Information Technology Education, 15.

[17] Dwyer, R. J., Kushlev, K., Dunn, E. W. (2018). Smartphone use undermines enjoyment of face-to-face social interactions. Journal of Experimental Social Psychology, 78, 233-239. doi:10.1016/j.jesp.2017.10.007

[18] Guragain, N. (2016). E-Learning benefits and applications. Bachelor of Engineering Information Technology. Helsinki Metropolia University of Applied Sciences. Retrieved 12/7/2018 from: https//www.ILeseus,fi>Guragain Nischal.

[19] Nortvig, A. M., Petersen, A. K., and Balle, S. H., (2018). A Literature Review of the Factors Influencing ELearning and Blended Learning in Relation to Learning Outcome, Student Satisfaction and Engagement. The Electronic Journal of e-Learning, 16(1), pp. 46-55

[20] Nguyen, T. (2015). The Effectiveness of Online Learning: Beyond No Significant Difference and Future Horizons. MERLOT Journal of Online Learning and Teaching. Vol. 11, No.2.

[21] Ullah, Obaid. (2018). Students' Attitude towards Online Learning at Tertiary Level.

[22] Guyer, Joshua \& Fabrigar, Leandre. (2015). The attitude-behavior link: A review of the history.

[23] Dursun, O. O., Donmez, O., \& Akbulut, Y. (2018). Predictors of Cyberloafing among Preservice Information Technology Teachers. Contemporary Educational Technology, 9(1), 22-41.

[24] Hussein, Z., Harun, A., \& Oon, S. W. (2016). The influence of the smartphone user's characteristics on the intention to use of M-health. International E-Journal of Advances in Social Sciences, 2(5), 598-602.

[25]Zabadi, A. M., \& Al-Alawi, A. H. (2016). University students' attitudes towards e-learning: University of Business \& Technology (UBT)-Saudi Arabia-Jeddah: A case study. International Journal of Business and Management, 11(6), 286295.

[26] Rhema, A., Miliszewska, I., \& Sztendur, E. (2013). Attitudes towards e-Learning and Satisfaction with Technology among Engineering Students and Instructors in Libya. Proceedings of the 2013 InSITE Conference.

[27] Peytcheva-Forsyth, R., Aleksieva, L., \& Yovkova, B. (2018, December). The impact of technology on cheating and plagiarism in the assessment-The teachers' and students' perspectives. In AIP conference proceedings (Vol. 2048, No. 1, p. 020037). AIP Publishing LLC.

[28] Brown, A. (1987). Metacognition, executive control, self-regulation, and other more mysterious mechanisms. Metacognition, motivation, and understanding.

[29] Hartnett, M. (2016). Motivation in online education. Singapore: Springer.

[30] Zhao, L. (2015). The Influence of Learners' Motivation and Attitudes on Second Language Teaching $\square$. Theory and Practice in Language Studies, 5(11), 2333-2339.

[31] Alario-Hoyos, C., Estévez-Ayres, I., Pérez-Sanagustín, M., Kloos, C. D., \& Fernández-Panadero, C. (2017). Understanding learners' motivation and learning strategies in MOOCs. The International Review of Research in Open and Distributed Learning, 18(3).

[32] de Barba, P. G., Kennedy, G. E., \& Ainley, M. D. (2016). The role of students' motivation and participation in predicting performance in a MOOC. Journal of Computer Assisted Learning, 32(3), 218-231.

[33] Chua, S. L., Chen, D. T., \& Wong, A. F. (1999). Computer anxiety and its correlates: a meta-analysis. Computers in human behavior, 15(5), 609-623.

[34] Achim, Nur’ain \& Kassim, Arraqib. (2015). Computer Usage: The Impact of Computer Anxiety and Computer Selfefficacy. Procedia - Social and Behavioral Sciences. 172. 701-708. 10.1016/j.sbspro.2015.01.422.

[35] Agah, J. J., Ogbeche, A. T., \& Okorie, E. U. (2016). Computer Anxiety, Operation Skills and Attitude As Correlates of Students Preparedness for Computer Based Assessment. International Journal of Education and Research, 4(2), 71-74.

[36] Salamah, I., Ganiardi, M. A., Kusumanto, R. (2015). Computer Anxiety and Computer Attitude towards Computer Self Efficacy (CSE) Polsri Telecommunication Engineering Student on Writing the Final Report. Proceeding of the Electrical Engineering Computer Science and Informatics, 2(1).

[37] Celik, V., \& Yesilyurt, E. (2013). Attitudes to technology, perceived computer self-efficacy and computer anxiety as predictors of computer supported education. Computers \& Education, 60(1), 148-158.

[38] Saade, Raafat \& Kira, Dennis. (2009). Computer Anxiety in E-Learning: The Effect of Computer Self-Efficacy. Journal of Information Technology in Education. 8. 177-191. 10.28945/166.

[39] Thinakaran, R., Ali, R., \& Husin, W. N. A. A. W. (2018). A Case Study of Undergraduate Students Computer Self-Efficacy from Rural Areas. International Journal of Engineering \& Technology, 7(3.20), 270-274. 
[40] Sahin Baltaci, H., \& Karatas, Z. (2015). Perceived Social Support, Depression and Life Satisfaction as the Predictor of the Resilience of Secondary School Students: The Case of Burdur. Eurasian Journal of Educational Research, 60, 111-130.

[41] Catabay, C. J., Stockman, J. K., Campbell, J. C., \& Tsuyuki, K. (2019). Perceived stress and mental health: The mediating roles of social support and resilience among black women exposed to sexual violence. Journal of Affective Disorders, 259, 143-149.

[42]Zhou, G., Gan, Y., Hamilton, K., \& Schwarzer, R. (2017). The Role of Social Support and Self efficacy for Planning Fruit and Vegetable Intake. Journal of Nutrition Education and Behavior, 49(2), 100-106.e1.

[43] Andi Wahyu Irawan .W., Dwisona D. Lestari M. (2020), Psychological Impacts of Students on Online Learning During the Pandemic COVID-19, Jurnal Bimbingan dan Konseling (E-Journal) 7(1):53-60,DOI: 10.24042/kons.v7i1.6389

[44] Lai, B. S., Kelley, M. L., Harrison, K. M., Thompson, J. E., \& Self-Brown, S. (2015). Posttraumatic stress, anxiety, and depression symptoms among children after Hurricane Katrina: A latent profile analysis. Journal of Child and Family Studies, 24(5), 1262-1270.

[45] Sawahel W (2020), Social media offers platform for online learning - Study, International Higher Education, Fall Issue, No. 104, 2020. 